\title{
Perkembangan Transportasi Kereta Api Di Jakarta
}

\author{
Jumardi ${ }^{1}$, Ruly $\mathbf{R}^{2}$, Abdulhadi ${ }^{3}$, Atika Siska ${ }^{4}$, Viki $\mathbf{A}^{5}$, Zaqi AZ ${ }^{6}$ \\ Pendidikan Sejarah FKIP UHAMKA \\ jumardi@uhamka.ac.id
}

\begin{abstract}
Abstrak
Transportasi kereta api di Indonesia umumnya dan Jakarta khususnya memiliki sejarah yang cukup panjang. Kereta Rel Listrik (KRL), Mass Rapid Transit (MRT) dan Light Rail Transit (LRT) merupakan perkembangan moda transportasi kereta api masa kini. Perkembangan transportasi tidak terlepas dari kepentingan penjajah dalam mengeksploitasi hasil bumi Indonesia. Hingga pada masanya kereta api menjadi angkutan massal yang murah. Metode penelitian menggunakan metode historis dan wawancara. Hasil penelitian diperoleh bahwa kereta api di Jakarta dimulai pada tahun 1869 hingga 1873. Pembangunan jalur kereta api diperuntukkan bagi pengangkutan hasil bumi di wilayah Buitenzorg ke batavia atau sebaliknya. Pada perkembangannya, kereta api dianggap mampu juga berperan sebagai angkutan tenaga kerja dan kemudian berkembang lagi menjadi angkutan massal di DKI Jakarta.
\end{abstract}

Kata Kunci : Transportasi, Kereta Api

\begin{abstract}
Absract
Rail transportation in Indonesia in general and Jakarta in particular has a fairly long history. Electric Rail Trains (KRL), Mass Rapid Transit (MRT) and Light Rail Transit (LRT) are the development of today's rail transportation modes. The development of transportation is inseparable from the interests of the colonizers in exploiting Indonesian agricultural products. Until the time the train became a cheap mass transportation. The research method uses historical methods and interviews. The results were obtained that the railroad in Jakarta began in 1869 until 1873. The construction of the railroad was intended for transportation of agricultural products in the Buitenzorg region to Batavia or vice versa. In its development, the train is considered capable of also acting as a transportation of labor and then developing again into mass transportation in DKI Jakarta.
\end{abstract}

Keywords : Transportation, Train

\section{A. Pendahuluan}

Perkembangan transportasi di Ibukota Jakarta menjadi lebih semarak dengan hadirnya Kereta Rel Listrik (KRL), Mass Rapid Transit (MRT) dan Light Rail Transit (LRT). Kehadiran ketiga moda transportasi ini diharapkan mampu mengatasi kemacetan yang menjadi bagian dari rutinitas masyarakat Jakarta. KRL, MRT dan LRT dapat dikatakan generasi terbaru layanan berbasis kereta yang sudah ada di Jakarta sejak 1925.

Transportasi kereta api di Indonesia umumnya dan Jakarta khususnya memiliki sejarah yang cukup panjang. Berkembangnya kapitalisme pada abad ke-19 di Belanda turut berpengaruh terhadap tanah jajahannya. Kehadiran kereta api di Indonesia secara umum atas desakan kaum industri dan kapitalis yang berada di parlemen Belanda, sehingga mendorng diterapkannya politik liberal dengan dikeluarkannya Undang-undang Agraria dan Undang-undang gula tahun 1870. Dengan demikian kereta api hadir untuk mendukung aktifitas dan kelancaran serta pengangkutan hasil produksi perkebunan.

Selain itu juga transportasi kereta hadir untuk memenuhi tujuan ekspor barang ke Pelabuhan Sunda Kelapa. Kehadiran kereta 
terus mengalami evolusi fungsi dari sekedar menjadi kendaraan angkutan menjadi moda transportasi penumpang.

Melihat perkembangan kereta api di Jakarta, Pemerintah Hindia Belanda akhirnya memilih kereta api sebagai angkutan jalan raya karena dinilai lebih cepat dan efektif jika dibandingkan angkutan jenis lain. Untuk keperluan ini, Pemerintah Hindia Belanda memutuskan untuk membangun jalur kereta api antara Buitenzorg hingga Batavia pada 1869 - 1873. Pekerjaan pembangunan jalur kereta api dipercayakan kepada perusahaan swasta Nederlansche-indische spoorweg Maatschappl (NISM). Penetapan perusahaan swasta tersebut untuk membangun jalur kereta api Bogor Jakarta karena dinilai berhasil dalam membangun jalur kereta api Semarang Timur (kemijen) - Tanggungharjo Grobogan pada tahun 1864 - 1867.

Nurhayati menjelaskan, kereta api sudah ada di Indonesia sejak tahun 1867. Sejarah perkeretaapian Indonesia tidak terlepas dari sejarah perjuangan Bangsa Indonesia dalam memperjuangkan kemerdekaan. Dalam perkembangannya, kereta api Indonesia sudah melalui empat masa, yaitu masa penjajahan Belanda, masa pejajahan Jepang, masa setelah kemerdekaan, dan masa modern (Nurhayati, 2014) Tanpa disadari, kereta api berperan sejak masa perjuangan hingga hari ini. Meskipun demikian banyak masyarakat umum belum mengetahui sejarah perkereta apian di Indonesia umumnya dan DKI Jakarta Khususnya sehingga dipandang perlu untuk melakukan penelitian tentang perkembangan perkeretaapian di DKI jakarta sebagai bagian dari warisan bangsa (Nurhayati, 2014).

\section{B. Metode Penelitian}

Metode dalam penelitian ini menggunakan metode penelitian historis dan wawancara. Husin Sayuti menjelaskan bahwa penelitian historis adalah prosedur pemecahan masalah dengan menggunakan data masa lalu atau peninggalan-peninggalan baik untuk memahami kejadian atau suatu keadaan yang berlangsung pada masa lalu terlepas dari keadaan masa sekarang dalam hubungannya dengan kejadian atau masa lalu, selanjutnya kerap kali juga hasilnya dapat dipergunakan untuk meramaikan kejadian atau keadaan masa yang akan datang. (Suyuti, 1989). Data diperoleh melalui peninggalan- peninggalan, dokumen-dokumen, dan arsip-arsip. Wawancara adalah proses memperoleh keterangan untuk tujuan penelitian dengan tanya jawab sambil bertatap muka antara si penanya atau pewawancara dengan si penjawab atau informan dengan menggunakan alat yang dinamakan interview guide (panduan wawancara). (Nasir, 1999) Wawancara merupakan cara mengumpulkan data melalui tanya jawab dilakukan secara sistematis dan dilandasi dengan tujuan penelitian.

\section{Hasil Penelitian}

Sejarah Transportasi Kereta Api di Jakarta Jalur Kereta Api Nederlandsche-Indische Spoorweg Maatschappij (NISM) Jakarta-Bogor 1869-1873

Kehadiran moda transportasi kereta api di Jakarta, dilatarbelakangi oleh kebutuhan transportasi yang lebih cepat dan efektif untuk mendukung kelancaran produksi dan pengangkutan hasil perkebunan dari Buitenzorg ke Batavia (Jakarta-Bogor) selain itu juga untuk ke Eropa melalui Pelabuhan Sunda Kelapa, yang selanjutnya bertransformasi untuk mengangkut penumpang.

Pemerintah Hindia Belanda memilih kereta api, karena dinilai lebih cepat dan efektif dibandingkan angkutan jalan raya. Pemerintah Hindia Belanda mempercayakan pembangunan jalur kereta api Batavia-Buitenzorg, kepada perusahaan swasta Nederlandsche-Indische Spoorweg Maatschappij (NISM) yang dinilai telah berhasil membangun jalur kereta api Samarang-Tanggungharjo pada tahun 18641867. (Ramadhan, 2017)

Pembangunan jalur ini dilakukan pada 15 Oktober 1869 dengan disaksikan langsung oleh Gubernur Jenderal Hindia Belanda, Mr. Pieter Mijer. Rencananya, pembangunan di semua bagian dilakukan secara serentak, namun pada tahun 1870 proyek ini sempat terhenti karena masalah keuangan. maka, pembangunan jalur tersebut dibangun secara bertahap dan dibuka untuk umum juga secara bertahap. 
Tahap pertama, jalur yang pertama dibuka adalah rute Pasar Ikan-Batavia NIS-Stasiun Gambir (Koningsplein) sejauh $9 \mathrm{~km}$ dengan 14 gerbong pada September 1871. kemudian, pada 16 Juni 1872 dijalankan kereta api jalur Gambir - Bukit Duri (Meester Cornelis), dan pada 31 Januari 1873 dibuka Jatinegara-Bogor. (Ramadhan, 2017)

Pembangunan jalur kereta api lainnya di Batavia juga dilakukan oleh perusahaan kereta api milik swasta Bataviasche Oosterspoorweg Maatschappij (BOSM). BOSM membangun jalur kereta api untuk lintas timur. Pembangunan jalur BOS dimulai pada tahun 1887 , jalur yang dibangun membentang dari Batavia Zuid (Batavia Selatan) - Bekassie (Bekasi). Seteah jalur tersebut diperpanjang hingga Karavam (Karawang), akhirnya jalur kereta api BOSM (Batavia-Karawang) diambil alih oleh Staatsspoorwegen pada tahun 1898. (A.D. Laksana., 2015)

Pada tahun 1875, Pemerintah HindiaBelanda mendirikan perusahaan kereta api negara Staatsspoorwegen. SS memulai peranannya di Batavia pada tahun 1880-an. Bemula dari pembangunan Stasiun Tanjung Priok lama; yang letaknya berada tepat di atas dermaga Pelabuhan Tanjung Priok. Stasiun ini selesai dibangun oleh Burgerlijke Openbare Werken pada 1883 dan baru pada tahun 1885 diresmikan pembukaannya bersamaan dengan pembukaan Pelabuhan Tanjung Priok. (Ibnu Murti., 2016). Jalur ini membentang dari Batavia - Tanjung Priuk yang kemudian diambil alih oleh SS pada tahun 1884, (A.D. Laksana., 2015). Selain itu, pada 1 Oktober 1899, SS telah menyelesaikan jalur kereta api yang dimulai dari Batavia menuju Tanahabang yang selanjutnya diperpanjang hingga Rangkasbitung menuju Anyer Kidul dengan cabang Duri-Tangerang. (Staatsspoorowegen, 1921).

Setelah beroperasinya semua segmen jalur kereta api di Jakarta, sebagai penghubung jalan kereta api di tengah, barat, dan timur, maka dibangunlah jalur penghubung kereta api Tanahabang-Salemba-Kramat (Interchange Cikini). Jalur kereta api tersebut adalah jalur kereta api yang dibuka sekitar tahun 1900, untuk menghubungkan 2 (dua) jalur KA yang dimiliki oleh Staatsspoorwegen (SS), perusahaan kereta api milik Pemerintah Hindia Belanda, yaitu jalur barat: Batavia (Jakarta)Anyer melalui Duri-Tanahabang dan jalur timur: Batavia (Jakarta)-Karawang melalui Pasar Senen-Jatinegara dengan memotong jalur kereta api milik Nederlandsch-Indische-SpoorwegMaatschappij (NIS) di dekat halte Pegangsaan sehingga membentuk jalur melingkar (ceinturbaan) di dalam kota Jakarta. (A.D. Laksana., 2015).

\section{Jalur Kereta Api Penghubung Baru}

Pada tahun 1913, jalur interchange Cikini mulai digantikan oleh interchange yang baru di Manggarai. Pembangunan jalur interchange baru ini dilakukan untuk menghilangkan rel dari Menteng. Rel yang baru ke Tanah Abang melalui selatan Menteng (di sisi utara Kanal Banjir Barat). Pembangunan stasiun Manggarai (eks stasion Boekit Doeri) juga telah menghilangkan stasion Meester Cornelis (yang fungsinya sebagai dipo Bukit Duri seperti yang ada sekarang). Pembangunan stasiun Manggarai dilakukan tahun 1914 dan selesai tahun 1918. Setelah pembangunan stasiun Manggarai, interchange antara stasiun Jatinegara dan stasiun Manggarai dan rel kereta api ke Tanah Abang via selatan Perumahan Menteng selesai, maka interchange Cikini tidak difungsikan lagi. (Matua Harahap., 2019). Dengan demikian, jalur kereta api yang ada di Batavia telah terhubung menjadi satu kesatuan utuh yang kini dikenal dengan Jalur Kereta Api Lintas Jakarta (Jabodetabek).

Bersamaan dengan adanya jalur penghubung (Interchange) kereta api yang baru, pada tahun 1913 jalur Batavia-Buitenzorg (NIS) dijual kepada pemerintah Hindia Belanda dan dikelola oleh Staatsspoorwegen. Dengan dijualnya jalur tersebut kepada $S S$, maka semua lintasan kereta api di Batavia dikuasai oleh $S \boldsymbol{S}$ yang menjadi cikal bakal dari PT KAI sekarang. (Gartikayati, 2012) . Setelah semua lintasan kereta api di Batavia dimiliki SS, untuk penataan ulang stasiun di Batavia, sekitar $200 \mathrm{~m}$ dari stasiun Batavia Noord dibangunlah Stasiun Batavia Zuid (Jakarta Kota yang sekarang). 
Pembangunannya selesai pada 19 Agustus 1929 dan secara resmi digunakan pada 8 Oktober 1929. Acara peresmiannya dilakukan secara besar-besaran dengan penanaman kepala kerbau oleh Gubernur Jendral jhr. A.C.D. de Graeff yang berkuasa pada Hindia Belanda pada 1926-1931. (kompas.com, 2009).

\section{Elektrifikasi Jalur Kereta Api Lintas Jakarta}

Wacana elektrifikasi jalur kereta api di Jakarta dan sekitarnya telah dilakukan oleh para pakar dari perusahaan kereta api milik pemerintah Hindia Belanda, Staatsspoorwegen (SS) sejak tahun 1917. Elektrifikasi ini diyakini akan menguntungkan secara ekonomi. Elektrifikasi pertama kali dilakukan untuk lintas Tanjungpriok- Meester Cornelis (Jatinegara). Proyek yang dimulai tahun 1923 ini selesai pada 24 Desember 1924. Untuk mendukung elektrifikasi, Dinas Tenaga Air dan Listrik kala itu membangun Pembangkit Listrik Tenaga Air (PLTA) "Oebroeg" /Ubrug dan PLTA "Kratjak" /Kracak di wilayah Sukabumi. Listrik selanjutnya mengalir ke Gardu Induk Ancol dan Jatinegara. Sementara listrik dari PLTA Kracak juga mendukung suplai LAA lintas Manggarai-Bogor melalui Gardu Induk Depok dan Kedungbadak (Bogor). (Arsip, 2019)

Pemerintah Hindia Belanda selanjutnya membeli sejumlah lokomotif listrik untuk menarik rangkaian kereta api. Lokomotif yang dibeli adalah seri 3000 buatan SLM (Swiss Locomotive \& Machineworks)- BBC (Brown Baverie Cie), seri 3100 buatan AEG (Allgemaine Electricitat Geselischaft) Jerman, seri 3200 buatan Werkspoor Belanda, serta KRL (Kereta Rel Listrik) buatan pabrik Westinghouse dan General Electric. Peresmian elektrifikasi jalur Tanjungpriok - Meester Cornelis kemudian dilakukan bersamaan dengan perayaan hari ulang tahun ke-50 SS pada April 1925. Elektrifikasi kemudian berlanjut dengan mengoperasikan lintas Batavia (Jakarta Kota)-Kemayoran, dan Meester Cornelis (Jatinegara)-Manggarai-Koningsplein (Gambir)-Batavia (Jakarta Kota). (Arsip, 2019)
Sejak 1 Mei 1927, di Kota Batavia melintas KRL yang mengelilingi kota (ceintuurbaan). Tahun 1930, untuk pertama kalinya jalur KRL Batavia (Jakarta Kota)-Buitenzorg (Bogor) beroperasi. Hingga tahun 1939, telah ada sebanyak 72 perjalanan KRL melintasi jalur lingkar Batavia dan Manggarai-Bogor. Setelah Indonesia merdeka, lokomotif listrik masih beroperasi di sekitar Jakarta. Namun karena usia kereta yang telah mencapai setengah abad , dan tidak ada penambahan lokomotif listrik baru, membuat transportasi dengan lokomotif listrik tidak lagi memadai. Perkeretaapian Jabodetabek kemudian mulai akrab dengan rangkaian KRL buatan Jepang yang mulai beroperasi tahun 1976. (Arsip, 2019)

Dikutip dari Historia.id, banyaknya perlintasan kereta api di pusat kota, menimbulkan permasalahan lalu lintas seperti kemacetan dan besarnya potensi kecelakaan antara KRL dan kendaraan bermotor. Untuk mengatasi permasalahan ini, pemerintah memperoleh bantuan dari konsultan transportasi asal Jerman Barat. Kajian konsultan Jerman Barat terangkum dalam tiga bagian: Jakarta Metropolitan Area Transportation Study (JMATS), Jakarta Mass Rapid Transit Study (JMRTS), dan Jakarta Rapid Transit Study Eastern Corridor (JRTSEC). Hasilnya Jalur KRL nantinya bukan hanya harus dipendam dalam perut bumi, tapi sebagian juga perlu diangkat ke udara. Biayanya terlalu tinggi. Tak terjangkau kocek pemerintah. Bahkan untuk meninggikan peron stasiun sejajar dengan pintu KRL pun, tak ada dana dari pemerintah. Zaman itu naik-turun KRL perlu usaha sedikit melelahkan. Sebab celah antara peron stasiun dan pintu masuk KRL terlalu tinggi. (Hendaru Tri Hanggoro., 2019)

Akhirnya pemerintah menjajaki kerja sama dengan Japan International Cooperation Agency (JICA), lembaga kerja sama teknik milik Jepang, dan Japan Railway Technical Services (JARTS), yang mengusulkan pembangunan jalur layang KRL pada rute tengah dari Manggarai sampai Kota sejauh 9,5 kilometer pada 1977. Mereka menyatakan siap membantu pengerjaan desain dan pencarian dananya. Pemerintah menyepakati saran JICA 
dan JARTS. Kemudian mereka membuat panitia pengarah bersama. Terdiri atas Departemen Perhubungan, Bappenas, Departemen Keuangan, Departemen Pekerjaan Umum, Pemerintah DKI Jakarta, dan PJKA. Tugasnya membuat rencana induk (master plan) pengembangan KRL Jabotabek hingga tahun 2000 bersama JICA dan JARTS. Rencana itu terbit pada 1981. Salah satu rencananya memasukkan pula pembangunan jalur layang rute tengah. Pembangunan ini menjadi prioritas. Sebab rute ini begitu padat penumpang. Untuk mengurangi kepadatan, armada KRL harus bertambah sehingga selang waktu keberangkatan bisa berkurang. (Hendaru Tri Hanggoro., 2019)

Dalam kajiannya JICA dan JARTS menawarkan 3 (tiga opsi) Pertama, pembangunan jalur layang tepat di atas jalur lama. Konsekuensinya seluruh perjalanan KRL harus dihentikan. Lamanya waktu pengerjaan 6 tahun 1 bulan dengan biaya Rp82,7 miliar. Kedua, pembangunan jalur layang berada di atas satu lajur KRL lama. Cara ini berbiaya lebih mahal, tetapi memiliki keuntungan pada waktu pengerjaan lebih singkat dan tidak menggangu perjalanan KRL. Ketiga, pembangunan jalur layang cukup di samping jalur lama. Biayanya memang mencapai Rp103,4 miliar, tetapi waktu pengerjaan hanya 4 tahun, dan KRL tetap beroperasi normalmaka pemerintah menyepakati untuk melakukan pembangunan jalur layang di samping jalur lama. Biayanya memang mencapai Rp103,4 miliar, tetapi waktu pengerjaan hanya 4 tahun, dan KRL tetap beroperasi normal. (Hendaru Tri Hanggoro., 2019)

Pemerintah akhirnya memilih opsi terakhir. Lebih mahal, tetapi tidak banyak menimbulkan masalah. Pembangunan jalur layang KRL berlangsung dalam beberapa tahap: kajian awal, pembebasan lahan, konstruksi, penambahan dua stasiun (Mangga Besar dan Jayakarta), pengangkatan stasiun, pemasangan teknologi kelistrikan dan persinyalan, dan uji coba KRL. Dimulai pada Februari 1988 dan berakhir pada awal 1992. Jalur layang KRL rute tengah kali pertama beroperasi pada 5 Juni
1992. Presiden Soeharto meresmikan jalur ini dengan menjajal naik KRL buatan Jepang dari Gambir menuju Kota. Berkat jalur layang ini, perjalanan KRL bisa lebih aman dan frekuensinya akan bertambah. Turut pula membantu naik-turun penumpang sebab tinggi peron dan pintu masuk kereta hampir sejajar. (Hendaru Tri Hanggoro., 2019)

\section{Trem Jakarta}

Satu lagi yang melengkapi moda transportasi roda besi di Batavia adalah trem (tram). (Matua Harahap., 2019). Jalur trem kuda pertama di Batavia diresmikan pada tanggal 10 April 1869 dan pada 1882 digantikan dengan trem uap. Trem ini dioperasikan oleh Bataviasche Tramweg Maatschappij (BTM) yang kelak berganti nama menjadi NederlandsIndische Tramweg Maatschappij (NITM). Trem ini menggunakan lebar sepur $1.188 \mathrm{~mm}$ dan lokomotif uap menjadi lebih efisien karena dapat menyingkat waktu perjalanan. (Maatschappij., 2019) Rute trem yang dikelola NITM, membentang dari Kota Intan hingga Kampung Melayu. Trem ini berjalan dari Tram stasion Kota Intan melalui stasion Batavia NIS dan stasion Batavia BOS, Glodok, Harmoni, lalu belok melaui Rijswijk (Juanda yang sekarang), Pasar Baroe, dan belok lagi ke Waterlooplein (Lapangan Banteng sekarang), Senen, Tanah Tinggi (tram stasion), lalu Kramat, Salemba, Matraman, Meester Cornelis (Jatinegara Timur yang sekarang) dan Kampung Melajo (tram stasion). Trem ini adalah trem uap (stoom tram). (Arsip, Kereta Api BataviaBuitenzorg Dioperasikan 31 Januari 1873; Tanah Partikelir Berkembang ; Trem Listrik Batavia, 1899., 1899)

Peningkatan jalur trem Batavia terus dilakukan dengan mengganti trem uap menjadi trem listrik pada tahun 1899, dan pada tahun 1909 sudah mencapai 14 kilometer. Trem listrik dioperasikan oleh perusahaan yang berbeda, yaitu Batavia Elektrische Tramweg Maatschappij (BETM). Kedua perusahaan ini kelak digabung pada tanggal 31 Juli 1930 sebagai Batavia Verkeers-Maatschappij (BVM). (Teuween, 2010.) Selain peningkatan dari trem uap ke trem listrik, trem juga mengalami 
peningkatan jalur yang dimulai dari Stasion Batavia (BOS) ke arah timur (sejajar rel) melalui Kemajoran, Goenoeng Sahari, Pasar Senen dan Tanah Tinggi lalu berbelok ke arah barat melalui Kwitang, Gondangdia dan seterusnya ke Tanah Abang (berakhir di halte Kanpong Djati). Sementara itu dari halte Kampong Djati Tanah Abang jalur trem ini menuju halte Harmoni. (Arsip, Kereta Api Batavia-Buitenzorg Dioperasikan 31 Januari 1873; Tanah Partikelir Berkembang ; Trem Listrik Batavia, 1899., 1899). Setelah Proklamasi Kemerdekaan Indonesia dikumandangkan, timbul ide untuk mengambil alih perusahaan BVM dan pada tahun 1957 dinasionalisasi menjadi Pengangkutan Penumpang Djakarta (PPD). Walaupun diambil alih, PPD hanya mengoperasikan trem tersebut selama beberapa waktu dan dihapuskan karena dianggap tidak cocok dengan tata ruang kota besar. (Shahab, 2004)

\section{Perkembangan Transportasi Kereta Api di Jakarta pada Masa Kini Ignasius Jonan (Direktur Utama KAI 2009 - 2014)}

Transformasi yang dilakukan oleh PT Kereta Api Indonesia identik dengan kepemimpinan Ignasius Jonan (Dirut PT KAI 2009-2014). Beliau berhasil menata jasa angkutan kereta api yang selama ini tidak tertata. Selain itu, beliau juga berhasil membuat perusahaan yang semula rugi menjadi untung. Sebelum tahun 2011 pelayanan kereta api jauh dari kata layak bahkan tidak manusiawi. Saat arus mudik, orang-orang rela berdesakan di stasiun dan memenuhi tempat-tempat yang peruntukkannya bukan untuk penumpang (seperti toilet, bordes, atap, lokomotif dan di lantai kereta) demi bisa pulang ke kampung halaman. Bukan bermaksud membiarkan, perusahaan beranggapan bahwa banyaknya penumpang maka akan meningkatkan keuntungan, yang terjadi bukannya membuat perusahaan untung justru sebaliknya.

Ternyata pendapatan yang masuk ke perusahaan tidak maksimal, penumpang yang tidak memiliki tiket tetap bisa naik kereta dengan cukup membayar kepada petugas ataupun masinis yang bertugas. Selain itu, tidak tertatanya pengelolaan aset komersial perusahaan (seperti kios atau ruko milik perusahaan yang berada di sekitar stasiun) menjadi celah bagi kepala stasiun untuk pekerjaan sampingan. Oleh karena itu, Jonan ingin semua itu berubah. Langkah pertama, Jonan memulai langkah perbaikan KAI dengan meningkatkan gaji pegawai agar kinerja mereka semakin meningkat. Dengan konsekuensi, tak ada lagi yang melakukan pekerjaan sampingan di KAI. Sehingga tidak ada kebocoran dana. (Khafifah, 2015)

Jonan juga melakukan perbaikan kinerja. Reward and punishment benar-benar diterapkan bagi seluruh pegawai KAI. Hal ini meningkatkan kepercayaan stakeholder. Bankbank berani memberikan kredit pada perusahaan yang masih merugi itu, sehingga KAI dapat menambah asetnya bahkan mampu melahirkan sebanyak 6 anak perusahaan. (Khafifah, 2015). Dan mampu mengaktifkan kembali jalur-jalur kereta api non aktif khususnya pada jalur Bogor-Sukabumi-Cianjur.

Kemudian beliau merubah mindset pegawai KAI menjadi customer first alias mengutamakan pelayanan pelanggan. Ketika pertama kali bergabung dengan KAI, Jonan mengatakan, "Hanya satu perubahan yang saya inginkan: mengalihkan (arah) organisasi ini dari product-oriented (keuntungan) ke customer focused (pelayanan)." Ia menginginkan seluruh jajaran Kereta Api berusaha membuat pelanggan lebih bahagia, maka infrastruktur perkeretaapian dibenahi. (Tempo.co, 2015). Stasiun dibuat steril dan menggunakan gate elektronik. PT Kereta Commuterline Jakarta (KCJ), anak perusahaan PT KAI mengalami peningkatan cukup pesat. Selain sarana dan prasarana, perbaikan SDM juga dilakukan. Jonan mengirimkan pegawainya ke luar negeri untuk mempelajari sistem perkeretaapian di sana. (Khafifah, 2015).

\section{Edi Sukmoro (Direktur Utama KAI 2014 Sekarang)}

Setelah sukses mereformasi PT KAI, akhirnya Ignasius Jonan harus digantikan oleh Edi Sukmoro pada 2014. Sebelum dilantik menjadi direktur utama, beliau bertugas sebagai 
direktur pengelolaan aset dan properti. Sejauh ini beliau terus melanjutkan pembenahan yang telah dilakukan oleh pak Ignasius Jonan sebelumnya serta melakukan serangkaian inovasi khususnya memberikan pelayanan terbaik pada pengguna jasa angkutan kereta api. Salah satunya dengan memprakarsai Rail Clinic. Rail Clinic hadir untuk memberi pelayanan lebih kepada masyarakat Indonesia khususnya di bidang kesehatan. Selanjutnya untuk memaksimalkan pelayanan kereta api khususnya pada aspek keamanan dan keselamatan, beliau melakukan peremajaan armada (misalnya dengan mendatangkan rangkaian-rangkaian dan lokomotif-lokomotif baru) serta renovasi di sejumlah stasiun-stasiun.

Selain fokus pada pelayanan, beliau juga mendorong perkembangan moda transportasi kereta api dalam kota atau perkotaan. Salah satunya dengan menghadirkan layanan kereta api bandara Soekarno-Hatta pada tahun 2017, serta membangun sejumlah kereta api bandara lainnya. Dalam rangka menambah daya angkut, beliau melakukan peningkatan sarana dan prasarana pendukung yakni dengan membangun double-double track yang bertujuan memisahkan kereta api jarak jauh dan jarak pendek atau local serta pembangunan double track jalur kereta api Jakarta-Surabaya via jalur selatan. Sebagai upaya perusahaan dalam menyeragamkan fasilitas dan memudahkan dalam penerapan tarif, kedepannya KAI hanya akan mengoperasikan dua kelas kereta, yaitu kelas Ekonomi (New Ekonomi 2016 dan Ekonomi Premium) dan kelas Eksekutif. Selain kereta api penumpang, PT KAI juga terus memasarkan kereta api angkutan barang.

Terakhir, PT KAI melalui Peraturan Presiden Nomor 65 Tahun 2016, dipercaya untuk mengoperasikan jalur LRT (Light Rail Transit) dari Cibubur, Cawang, Dukuh Atas dan Bekasi Timur, Cawang, Dukuh Atas. Perpres ini langsung menugaskan PT Kereta Api Indonesia (Persero) yakni DAOP 1 Jakarta sebagai penyelenggara sarana, meliputi pengadaan sarana, pengoperasian sarana, perawatan sarana, dan pengusahaan sarana, penyelenggaraan sistem tiket otomatis dan menyelenggarakan pengoperasian dan perawatan prasarana. (Agustine, 2016)

\section{Kesimpulan}

Sejak awal kehadirannya hingga masa kini perkembangan moda transportasi kereta api di Jakarta mengalami pasang surut serta perjalanan yang cukup lama untuk dapat menjadi moda transpotasi kereta api seperti yang sekarang ini. Dalam konteks transportasi massal, sebagian pengamat dan pakar transportasi menilai bahwa ibukota Jakarta mengalami keterlambatan/ketertinggalan dalam membangun transportasi massalnya. Setelah mengalami kejayaan di era kolonial Belanda, moda tranportasi kereta api justru mengalami penurunan kualitas di era kemerdekaan karena usia sarana dan prasarana perkeretaapian yang semakin menua. Bahkan moda tranportasi trem telah lama ada di Jakarta harus digantikan oleh moda transportasi bus karena sudah tidak memadai untuk memenuhi kebutuhan transportasi di perkotaan sebesar ibukota Jakarta.

Moda transportasi kereta api belum menunjukkan perkembangan yang cukup signifikan di era orde baru. Namun gagasangagasan hasil kajian-kajian strategis yang dilakukan atas kerjasama dengan Jepang kala itu memberikan pengaruh bagi perkembangan transportasi berbasis rel di Jakarta pada masa kini. Hingga era orde baru berakhir, wajah kereta api di Jakarta malah semakin jauh dari kata manusiawi. Setelah tahun 2011, moda transportasi kereta api di Jakarta baru menunjukkan perkembangan yang cukup signifikan di berbagai aspek khususnya pada aspek pelayanan sehingga menghasilkan kenaikan jumlah penumpang yang cukup drastis daripada masa-masa sebelumnya. Dan moda transportasi kereta api mencapai puncaknya pada hari ini yakni dengan selesainya pembangunan transportasi berbasis rel yang dikenal dengan Mass Rapid Transit (MRT) dan Light Rapid Transit (LRT).

Perkembangan yang dihasilkan moda transportasi kereta api telah memberikan manfaat bagi pengguna jasa kereta api di Jakarta, terutama dalam meningkatkan kualitas 
pelayanan. Dengan semakin meningkatnya jumlah pengguna jasa angkutan kereta api di Jakarta, KAI selaku operator akan terus melanjutkan pembangunan dan pengembangan jalur dan layanan KA, sehingga merubah wajah kereta api di Jakarta menjadi moda transportasi yang nyaman, aman, tepat waktu, dan modern. (Persero, 2014). Hal ini tidak lepas dari transformasi yang dilakukan oleh KAI dalam mengembangkan usahanya.

Transformasi yang dijalankan KAI adalah bertekad untuk terus melanjutkan dan menyempurnakan inovasi yang telah diciptakan pada hampir seluruh aspek Perusahaan. Inovasi tersebut, diharapkan dapat memberikan value added bagi pengguna jasa sehingga meningkatkan kepercayaan masyarakat dalam menggunakan jasa perkeretaapian Indonesia secara berkelanjutan.(Persero), 2015)., Oleh karena itu, KAI berkomitmen untuk terus memberikan pelayanan terbaik bagi seluruh pengguna jasa angkutan kereta api.

\section{Daftar Pustaka}

(Persero), P. K. (2015). Laporan Keberlanjutan 2015: Transformasi yang Berkelanjutan untuk Indonesia. . Jakarta: Dokumen Perusahaan.

A.D. Laksana., d. (2015). Jalur Kereta Api Cikini - Salemba - Pabrik Opium. Jakarta: Pusat Data, Informasi dan Kepustakaan Kereta Anak Bangsa Edisi 17 Nopember 2015.

Agustine, I. (2016, Agustus 15). Perpres LRT Terintegrasi Direvisi, Kemenhub Diminta Selesaikan Desain dan Spesifikasi Teknis. Retrieved Juni 20, 2019, from Ekonomi Bisnis com: https://ekonomi.bisnis.com/read/20160 815/98/575303/perpres-lrt-terinte grasidirevisi-kemenhub-diminta-selesaikandesain-dan-

Arsip. (1899). Kereta Api Batavia-Buitenzorg Dioperasikan 31 Januari 1873; Tanah Partikelir Berkembang ; Trem Listrik Batavia, 1899. Batavia: Trem Listrik Batavia, 1899.
Arsip. (2019). Arsip Kesejarahan PT. Kereta Commuter Indonesia. . Jakarta: Diakses dari http://www.krl.co.id/ pada 20 Juni 2019.

Gartikayati, T. (2012, Juni Selasa). https://www.kompasiana.com/galing/55 16e9dc813311ab64bc6136/ngabuburitmenelusuri-sejarah-perkereta-apian-dibatavia.'page=all pada 20 Juni 2019.

Retrieved Juni selasa, 2019, from https://www.kompasiana.com/galing/55 16e9dc813311ab64bc6136/ngabuburitmenelusuri-sejarah-perkereta-apian-dibatavia?page=all pada 20 Juni 2019.: https:/www.kompasiana.com/galing/55 16e9dc813311ab64bc6136/ngabuburitmenelusuri-sejarah-perkereta-apian-dibatavia?page=all pada 20 Juni 2019 .

Hendaru Tri Hanggoro., (. (2019). Awal Mula Jalur Layang Kereta di Indonesia. Jakarta: https://historia.id/urban/articles/awalmula-jalur-layang-kereta-di-indonesiavYE0Q pada 20 Juni 2019.

Ibnu Murti., H. (2016). Arsitektur bangunan Station Kereta Api di Indonesia. Jakarta: PT Kereta Api Indonesia (Persero).

Khafifah, N. (2015, Juni 20). Kisah Jonan Perbaiki KAI: dari Rapor Merah hingga Untung hampir $R p 1 T$. Retrieved Juni 20, 2019, from Diakses dari https://news.detik.com/berita/d2938862/kisah-jonan-perbaiki-kai-darirapor-merah-hingga-untung-hampir-rp1-t pada 20 Juni 2019.: https://news.detik.com/berita/d2938862/kisah-jonan-perbaiki-kai-darirapor-merah-hingga-untung-hampir-rp1-t pada 20 Juni 2019.

kompas.com. (2009, 2009 kamis). Stasiun Batavia Selatan Genap 80 Tahun. Retrieved Juni Selasa, 2019, from Kompas.com. 2009. Stasiun Batavia Selatan Genap 80 Tahun.Diakses darihttps:/internasional.kompas.com/r ead/2009/10/23/10494612/stasiun.batav iaselatan.genap.80.tahun pada 20 Juni 2019.: Diakses

Vol. 7, No.1, April 2020, 40-48 |47 
darihttps://internasional.kompas.com/r ead/2009/10/23/10494612/stasiun.batav iaselatan.genap.80.tahun pada 20 Juni 2019.

Maatschappij., N.-I. T. (2019). NederlandsIndische Tramweg Maatschappij. Nederland-Indies: Diakses dari http://searail.malayanrailways.com/PJK A/Nederland-Indies\%20Tramway/ NITM.htm pada 20 Juni 2019.

Matua Harahap., A. (2019, Juni selasa). http://poestahadepok. Retrieved Juni 20, 2019, from blogspot.com/2016/12/sejarah-jakarta9-kereta-api-batavia.html pada $20 \mathrm{Juni}$ 2019:

http://poestahadepok.blogspot.com/20 16/12/sejarah-jakarta-9-kereta-apibatavia.html pada 20 Juni 2019

Nasir, M. (1999). Metode Penelitian Cetakan

Kedua . Jakarta: Ghalia Indonesia.

Nurhayati, Y. (2014). Sejarah Kereta Api. Kalten: CV Rizki Mandiri .

Persero, P. K. (2014). Company Profile PT Kereta Api Indonesia (Persero): Komitmen terhadap Inovasi dan Kualitas Pelayanan . Jakarta: Dokumen Perusahaan.

Ramadhan, A. P. (2017, desember sabtu). Pengaruh Jalur Kereta Api BataviaBuitenzorg terhadap Kehidupan Sosial dan Ekonomi Masyarakat tahun 18711913. Retrieved 2016 12, 2017, from http://library.fis.uny.ac.id/elibfis.: http://library.fis.uny.ac.id/elibfis.

Shahab, A. (2004). Saudagar Baghdad dari Betawi. Jakarta: Penerbit Republika.

Staatsspoorowegen. (1921). Verslag der staatsspoor-en-Tranwegen in Nederlandsch-Indie 1921-1932. Batavia: Burgerlijke Openbare Werken.

Suyuti, H. (1989). Pengantar Metodologi Riset. Jakarta: Fajar Agung.

Tempo.co. (2015, Juni 20). Nama Jonan Identik dengan Tranformasi di KAI. Retrieved juni 20, 2019, from tempo.co : https://bisnis.tempo.co /read/450247/nama-jonan-identik- dengan-transformasi-dikai/full\&view=ok pada 20 Juni 2019. Teuween, D. (2010.). From horsepower to electrification Tramways in BataviaJakarta. Jakarta: Batavia-Jakarta. 